\title{
Bank Deposit Growth in the Eighth Federal Reserve District
}

\section{S} UUBSTANTIAL VARIATION EXISTS in the growth rate of bank deposits among regions as well as among individual banks within a region. This article reviews the growth trends of banks in the Eighth Federal Reserve District since 1950. Deposit growth rates are presented for all insured banks in each metropolitan area, for the nonmetropolitan areas of the district, and for each individual bank with over $\$ 25$ million in deposits. Possible reasons for the variation in growth trends are examined.

Total deposits of member banks in the Eighth Federal Reserve District rose 5.3 per cent during the past year. Member bank deposits in the nation rose 5.4 per cent, while deposits of all commercial banks rose about 6 per cent. Commercial bank deposits both in the Eighth District and in the nation grew somewhat less than in most other recent years. District bank deposits rose at an average rate of 3.8 per cent per year during the $1950-60$ period and at an 8 per cent rate from mid-1960 to mid-1966. Commercial bank deposits in the nation rose at average rates of 3.9 per cent and 8 per cent, respectively, during the two periods.

The volume of demand deposits nationally is largely determined by Federal Reserve actions in providing reserves to support these deposits. Using reserves as a base, the banking system creates deposits through the addition of loans and investments to bank assets. ${ }^{1}$

\footnotetext{
'Proceeds of loans and investments are credited to customers' deposit accounts and remain as deposits until the loan is repaid even though they are spent, unless some holder to which the funds have passed converts them to time or savings deposits or withdraws them as cash. This process of lending and investing and of deposit creation, in the banking system as a whole, can continue as long as bank reserves are sufficient to meet legal reserve requirements.

Holders of demand deposits may convert them to time or savings deposits, which have lower legal reserve requirements. In this case, banks will find that they have excess reserves and can create additional deposits. On the other hand, if time and savings deposit holders choose to convert their deposits to demand deposits or transfer them to other
}

During the first half of the 1960 's time and savings deposits at commercial banks grew rapidly. Time deposits in the district rose at a 16 per cent rate from mid-1960 to mid-1966 after increasing at a 7 per cent rate in the $1950-60$ period. In the nation time deposits increased at a 15 per cent rate during the 1960-66 period compared with an annual growth rate of 6 per cent in the 1950 's. The substantial growth in time and savings accounts in the more recent period is the result of increased aggressiveness by commercial banks in seeking funds to meet a rising demand for credit. Reflecting this increased competition for funds were more liberal interest rates paid on time and savings deposits and the issue of unsecured notes, subordinated debentures, and an increasing variety of certificates of deposit.

Demand deposits have grown less rapidly than time and savings deposits. Demand deposits at district banks increased at a 2.8 per cent annual rate during the $1950-60$ period and at a 3.6 per cent rate from 1960 to 1966. In the nation demand deposits rose at rates of 2.7 and 3.7 per cent, respectively.

\section{Deposit Growth Among District States}

Differences in the growth rates of deposits in various areas are influenced by numerous economic forces including income, saving, interbank competition, and competition between banks and other financial institutions. Demand deposits are generally held as a convenient means for settling day-to-day trans-

\footnotetext{
financial institutions, commercial banks will be short of reserves and must reduce their assets in order to bring deposits back to levels conssstent with reserves.

Legal reserves of Federal Reserve member banks include cash in the vatilt plus deposits at the Federal Reserve Bank. Reserve requirements were as follows as of Decenber 31 , 1966: $16 \%$ per cent on net demand deposits at reserve city banks, 12 per cent on net demand deposits at country banks, 4 per cent on savings deposits and on other time deposits up to $\$ 5$ million, and 6 per cent on time deposits in excess of $\$ 5$ million.
} 
actions and as a means of storing wealth. Although changes in these deposits in the nation are largely determined by the Federal Reserve in supplying reserves to the banking system, growth of demand deposits in a local area is likely to be related to the growth of both income and wealth of the community.

Time and savings deposits, in addition to their relationship to income and wealth, are perhaps as. sociated with the convenience and competitive features of banks relative to other savings mediums. Thus, such deposit growth in an area may be associated with the number of banking offices, rates of interest paid by banks relative to other financial intermediaries, and other alternative opportunities for investing savings.

All areas of the district have had sizable gains in total deposits since 1950. In the portions of states within the Eighth District, ${ }^{2}$ the rate of increase during the 1950-60 period ranged from 3.1 per cent per year in Indiana to 5.2 per cent in Mississippi (Table I). During the 1960-66 period Arkansas had the most 10 per cent per year, while Illinois, with a rate of 7 per cent, had the lowest rate of gain. In every state of the district growth of time and savings deposits was considerably more rapid than that of demand deposits. Also, variation among states in the rate of growth of time and savings deposits was greater than for demand deposits.

As indicated earlier, growth of time and savings deposits is influenced by rates of interest paid. Four states in the district-Arkansas, Indiana, Mississippi, and Tennessee-limit rates paid on such accounts. Maximum rates payable in these states in recent years have generally been below the national Regulation Q limits. ${ }^{3}$ Furthermore, many banks pay considerrapid increase, with total deposits rising at a rate of

Table 1

\section{DEPOSIT GROWTH \\ AT EIGHTH DISTRICT INSURED BANKS \\ Annual Rates of Increase}

\begin{tabular}{|c|c|c|c|c|c|c|}
\hline & \multicolumn{2}{|c|}{ Totat Deposits } & \multicolumn{2}{|c|}{ Time Deposits } & \multirow{2}{*}{$\frac{\text { Demand }}{1950-60}$} & \multirow{2}{*}{$\frac{\text { Deposits }}{1960.66}$} \\
\hline & $1950-60$ & $1960-66$ & $1950-60$ & $1960-66$ & & \\
\hline \multicolumn{7}{|l|}{ Stale portions: } \\
\hline Atkansas & 4.4 & 9.9 & 11.2 & 17.1 & 2.9 & 5.7 \\
\hline Illinois & 3.7 & 6.9 & 5.2 & 11.9 & 2.7 & 3.3 \\
\hline Indiano & 3.1 & 8.9 & 3.9 & 14.5 & 2.3 & 4.9 \\
\hline Kentueky & 4.0 & 7.5 & 7.7 & 18.9 & 3.3 & 3.2 \\
\hline Mississippi & 5.2 & 8.4 & 12.6 & 17.0 & 2.9 & 5.3 \\
\hline Missouri & 3.4 & 7.3 & 5.6 & 15.8 & 2.8 & 2.3 \\
\hline Tennessee & 4.3 & 9.3 & 9.4 & 14.7 & 2.5 & 5.0 \\
\hline Eighth District & 3.8 & 8.0 & 6.8 & 15.5 & 2.8 & 3.6 \\
\hline
\end{tabular}

1 Deposits of individuals, partnerships, and corporations.

ably less than the maximum rates permitted. At midyear 1966 one-fourth of all insured commercial banks in the district were paying less than 3 per cent interest on regular savings accounts, and one-eighth of the banks were paying less than that amount on other time deposits (Table II). About one-tenth of the banks paid less than 3 per cent on both savings and time deposits. On the other hand, almost one-third of the banks were paying the maximum of 4 per cent on regular savings accounts. Nearly half of the banks were paying between 4.5 and 4.9 per cent on other time deposits, while one-eighth of the banks paid 5 per cent or more on these accounts. These data indicate that for many banks in the district the opportunity may exist for attracting additional funds by increasing the rates paid on time and savings deposits.

Apparently, interest rate limitations did not adversely affect deposit growth during much of the 1950-65 period in those states which have such reg. ulations. While time and savings deposits in the Indiana portion of the district grew more slowly

2The Eighth District includes all of Arkansas, all of Missouri except the western tier of counties, the southem third of Illinois, the southern fourth of Indiana, the western half of Kentucky, the western third of Tennessee, and the northern half of Mississippi.

3 At the end of 1966 , Regulation $Q$ specified that the maximum interest that any member bank could pay was 4 per cent on savings deposits and all multiple. maturity time deposits of less than 90 days, 5 per cent on single-maturity time deposits of less that $\$ 100,000$ and all multiple-maturity deposits of 90 days or more, and $5 \frac{1}{2}$ per cent on single-maturity time deposits of $\$ 100,000$ and over. Maximum rates payable by nonmember insured commercial banks, established by the Federal Deposit Insurance Corporation, were the same as the above.

\section{Table 1 \\ INTEREST PAID ON TIME AND SAVINGS ACCOUNTS EIGHTH DISTRICT INSURED BANKS \\ fune 30,1966 \\ Percentage Distribution of Banks}

\begin{tabular}{l} 
Rate of Interest \\
On Regular Savings \\
Deposits \\
\hline Under 3.0 \\
$3.0-3.4$ \\
$3.5-3.9$ \\
4.0 \\
Tolal
\end{tabular}

\begin{tabular}{|c|c|c|c|c|c|}
\hline \multicolumn{6}{|c|}{ Rate of Interest on Other Time Deposits ${ }^{t}$} \\
\hline Under 3.0 & $3.0 \cdot 3.9$ & $4.0-4.4$ & $4.5 \cdot 4.9$ & $5.0-5.4$ & Tota! \\
\hline 9.62 & - & 9.14 & 5.78 & 0.61 & 25.15 \\
\hline 1.95 & 4.57 & 6.66 & 10.89 & 5.92 & 29.99 \\
\hline 0,13 & - & 2.29 & 10.49 & - & 12.91 \\
\hline- & 0.27 & 5.45 & 19.71 & 6.52 & 31.95 \\
\hline 11.70 & 4.84 & 23.54 & 46.87 & 13.05 & 100.00 \\
\hline
\end{tabular}

1 Rates paid are not necessarily the highest, but are the most common, rates paid Sowrf: 1966 Agricultural Loan Survey conducted by the Federal Reserve System. 
than in most other areas during the 1950's, Arkansas, Mississippi, and Tennessee showed the most rapid time deposit gains in the district. Since 1960 the rate of time deposit growth in these states has approximated that of the entire district. The market rate of interest during much of the period examined was below the rates banks in these states were permitted to pay. Under such a situation, banks can effectively compete for time and savings deposits. When market rates moved above permitted bank rates, however, a greater share of funds flowed into other intermediaries or into the credit and equity markets, As a result, growth in bank deposits was hampered.

Interest rates are not the only factor affecting time deposit growth. Growth in incomes and alternative opportunities for investing savings have also been important determinants of deposit growth. However, in much of the period since 1960 bank deposits have increased more rapidly than incomes and savings. Stated somewhat differently, banks have been successful, during most of the period examined, in obtaining a greater share of the public's savings.

\section{Deposit Grotth in Metropolitan and Nonmetropolitan Areas}

Since 1950 bank deposits have increased more rapidly at banks located in nonmetropolitan areas than at metropolitan banks. Total deposits at banks in the smaller cities and rural areas of the district rose at an annual rate of 9 per cent during the 1960-66 period compared with a 7 per cent rate at metropolitan banks (Table III). During the 1950's total deposits at nonmetropolitan banks increased at a 4 per cent rate, and at metropolitan area banks, at a 3 per cent rate.

From 1.960 to 1966 time deposits of nonmetropolitan area banks increased at a 16 per cent rate, and those of metropolitan area banks rose at a 15 per cent rate. During the 1950-60 period time deposits rose at an average rate of 10 per cent at nonmetropolitan banks compared with an average rate of 5 per cent at metropolitan banks. Except for the Indiana and Illinois portions of the district, nonmetropolitan areas showed an increase in time deposits in excess of the growth of such deposits in any of the district metropolitan areas (Table III). While the growth was slower in Indiana and Illinois than in other district states during the 1950's, it was slightly above the average increase in all metropolitan areas of the district.

The rate of growth of demand deposits at metropolitan banks during the 1950-60 period was slightly greater than at nonmetropolitan banks, 3.0 per cent ammually compared with 2.6 per cent. However, since 1960 this situation has reversed, with demand deposits in smaller centers increasing at a rate of 4.5 per cent annually compared with 2.7 per cent for larger city banks.

\section{Individual Bank Growth}

While some areas of the district have shown more rapid deposit growth than others since 1950, an even greater variability appears when individual banks are compared. Deposit growth at banks with deposits of $\$ 25$ million and over in 1966 was quite rapid at a very few banks in each of the large metropolitan areas. In Little Rock, Louisville, and Memphis a single bank grew two to three times as rapidly as any other bank in the particular area during the $1950-60$ period (Table IV). Since 1960 the magnitude of growth variation

Table III

DEPOSIT GROWTH AT METROPOLITAN AND NONMETROPOLITAN AREA BANKS IN EIGHTH DISTRICT Annual Rates of Increase

\begin{tabular}{|c|c|c|c|c|c|c|}
\hline & \multicolumn{2}{|c|}{ Total Deposits } & \multicolumn{2}{|c|}{ Time Deposits ${ }^{1}$} & \multicolumn{2}{|c|}{ Demand Deposits ${ }^{2}$} \\
\hline & 1950.60 & $1960-66$ & 1950.60 & $1960-66$ & $1950-60$ & 1960.66 \\
\hline \multicolumn{7}{|c|}{ Metropolitan areas: } \\
\hline Sf. Louis & 3.1 & 6.8 & 4.1 & 14.0 & 2.7 & 1.8 \\
\hline Louisville & 4.0 & 7.3 & 3.9 & 20.1 & 4.3 & 2.5 \\
\hline Memphis & 4.1 & 9.3 & 8.4 & 14.8 & 2.8 & 4.9 \\
\hline Litfle Rock & 4.9 & 8.8 & 8.5 & 16.4 & 4.3 & 4.9 \\
\hline Evansvisle & 1.7 & 7.2 & 1.1 & 13.0 & 1.7 & 3.5 \\
\hline Springfield & 4.2 & 8.9 & 6.3 & 21.0 & 3.7 & 4.3 \\
\hline Fort Smith & 2.5 & 9.1 & 4.8 & 15.5 & 2.2 & 6.0 \\
\hline Pine Bluff & 3,4 & 9.8 & 5.2 & 13.4 & 2.3 & 4.7 \\
\hline Total & 3.4 & 7.4 & 4.7 & 14.9 & 3.0 & 2.7 \\
\hline \multicolumn{7}{|c|}{$\begin{array}{l}\text { Nonmetropoliton areas } \\
\text { in district: }\end{array}$} \\
\hline Arkansas & 4.5 & $\$ 0.3$ & 13.6 & 17.6 & 2.6 & 5.8 \\
\hline Iltinois & 3.9 & 7.5 & 6.8 & 12.6 & 2.3 & 3.7 \\
\hline Indiand & 3.7 & 9.9 & 5.8 & 15.2 & 2.3 & 5.8 \\
\hline Kenfucky & 4.1 & 7.9 & 13.6 & 17.4 & 2.4 & 4.1 \\
\hline Mississippi & 5.2 & 8.4 & 12.6 & 17.0 & 2.9 & 5.3 \\
\hline Missouri & 4.3 & 8.1 & 11.1 & 18.8 & 3.1 & 3.3 \\
\hline Tennessee & 4.8 & 9.5 & 12.9 & 14.8 & 2.0 & 5.7 \\
\hline Tolal & 4.3 & B.6 & 10.1 & 16.2 & 2.6 & 4.5 \\
\hline
\end{tabular}

Deposits of individuals, partnerships, and corporations. 
among individual banks in these areas has lessened slightly. In the St. Louis area three banks showed extremely rapid growth (over 10 per cent yearly), while six banks grew at quite modest rates of under 2 per cent annually during the 1950-60 period.

With few exceptions the most rapidly growing banks during the 1950-60 period have also been the fastest growing in the more recent period. In most cases the rapidly growing banks in each of the metropolitan areas were relatively small institutions in 1950 , generally not more than one-tenth the size of the largest banks in the area. None of these rapidly growing banks had attained the position of largest bank in its particular area in 1966, although the gap

Table IV

\section{DEPOSIT GROWTH OF INDIVIDUAL BANKS IN EIGHTH DISTRICT}

Antual Rotes of lincreose

METROPOLITAN AREAS

$1950-60 \quad 1960-66$

St Louis, Missouri-lllinois

Deposits $\$ 100$ miltion ond over

$\begin{array}{lll}\text { Bank A } & 8.4 & 8.2 \\ \text { Bank B } & 2.1 & 7.2 \\ \text { Bank C } & 3.0 & 5.9 \\ \text { Bank D } & 2.9 & 5.4 \\ \text { Bank E } & 0.9 & 5.2 \\ \text { Bank F } & 1.3 & 4.4 \\ \text { Bank C } & 2.7 & 0.8\end{array}$

Deposits $\$ 50-\$ 100$ milition

Bank A.

Bank B

Bank C

Bank D

Bonk E

Deposils $\$ 2550$ million

\begin{tabular}{|c|c|}
\hline Bank A & 3.0 \\
\hline Bank B & 7.9 \\
\hline Bonk C & 9.9 \\
\hline Bank D & 8.9 \\
\hline Bank E & 5.1 \\
\hline Bank & 8.7 \\
\hline Bank $G$ & 6.8 \\
\hline Bonk H & 2.4 \\
\hline Bank I & 6.3 \\
\hline Bank J & 2.9 \\
\hline Bank K & $2.0^{\circ}$ \\
\hline Bank L & 4.5 \\
\hline Bonk $M$ & 29.5 \\
\hline Bank N & 1.0 \\
\hline Bonk 0 & 1.2 \\
\hline Bank $P$ & 4.7 \\
\hline Bank $\mathrm{Q}$ & 7.8 \\
\hline Bank R & 4.2 \\
\hline Bonk $\mathbf{S}$ & 7.2 \\
\hline Bank T & 2.7 \\
\hline Bank U & 4.0 \\
\hline Bonk V & 0.7 \\
\hline Bank W & 1.9 \\
\hline
\end{tabular}

Deposits over $\$ 25$ million
$1950-60 \quad 1960-66$

Little Rock

Bank A

Bonk B

Bank C

Bank D

Louisville

Bank A

Bank B

Bank C

Bank D

Benk E

Memphis

Bank A

Bonk $B$

Bank C

Bank D

Bank E

Forf $\mathrm{Smith}$

Bank A

Bonk B

Bank C

Pine Bluft

Sank A

Bank

Evansuille

Bank A

Bank $B$

Bank C

Springfield

Bonk A
Bonk B

$6.5 \mathrm{14} / 2$

$1,7 \longdiv { 8 } 8,5$

$0.9+? 6,0$

$6.4 \quad 9.5$

NONMETROPOUITAN AREAS

$1950-60 \cdot 1960-66$

Deposits over $\$ 25$ million

Arkanses

\begin{tabular}{|c|c|}
\hline Bank A & 5.0 \\
\hline Bank B & 4,4 \\
\hline Bank C & 3.9 \\
\hline Bank D & 3.9 \\
\hline BankE & 2.0 \\
\hline Bonk F & 2.0 \\
\hline Bank $G$ & 1.9 \\
\hline
\end{tabular}

Ilinois and Indiana

BonkA $2.5 \quad 8.5$

$\mathrm{Bank} B \quad 2.3 \mathrm{7} 2$

Bank C आ का 1 6.1

Bank D 3.83 5.!

Kentucky

Bank A

$\mathrm{BankB}$

$\mathrm{BankC}$

Bork $\mathrm{D}$

BomkE

$\mathrm{Mis} / \mathrm{ss} \mathrm{pp}$;

$\operatorname{Bank} \mathrm{A}$

Bank B

BankC

Bonk D

Bom

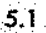

Missouri

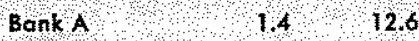

Balk B o $\quad 32$ ? 9.4

$33 \quad 00$

Tennessee

$\begin{array}{rr}\text { BankA } & 4.5 \\ \text { BankB } & 9.3 \\ 2.9 & 77\end{array}$

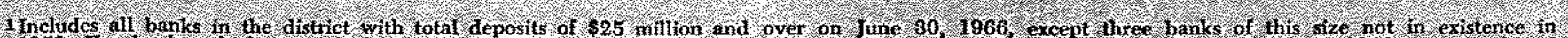

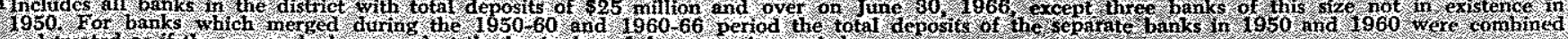

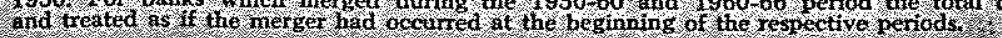


between the rapidly growing banks and their larger competitors closed considerably during the period examined.

These data indicate that small, well-managed, aggressive institutions have been able to attract an in creasing proportion of the banking business of a community. While growth does not necessarily insure competition or profits, these smaller but rapidly growing banks must be providing new or improved services sought by banks' customers or meeting these demands at lower costs. Through such innovations they may exert a considerable competitive impact on other banks in the metropolitan area.

Banks in St. Louis with over $\$ 100$ million of deposits in 1966 have grown less rapidly than similar banks in other metropolitan areas of the district. Deposits of such banks in the St. Louis area have grown 5 per cent annually since 1960 compared with average rates of 9 per cent in Memphis and 8 per cent in Little Rock and in Louisville. During the 1950-60 period major St. Louis banks grew at an average annual rate of 1.7 per cent, while major banks in these other cities rose at about a 4 per cent rate.

One probable explanation for the less rapid growth of large St. Louis banks is their limited opportunity for providing banking services to the rapidly growing suburban communities. Banks in most other metropolitan areas of the district can provide such services through branches and additional offices, while banks in St. Louis are largely confined to their existing location.

William E. Pettighew Climton B. Luttrell 